\title{
Poppy Seed Oil
}

National Cancer Institute

\section{Source}

National Cancer Institute. Poppy Seed Oil. NCI Thesaurus. Code C66451.

The edible oil extracted from the seeds of Papaver somniferum. Poppy seed oil is used as a cooling oil and food ing redient as well as in pharmaceutical products. It is also used as an ing redient in paints, varnishes, and soaps. 